\title{
Present validity of "maximal" thymectomy in the treatment of myasthenia gravis
}

\author{
Joshua R. Sonett \\ Department of Thoracic Surgery, Columbia University, New-York Presbyterian Hospital, New York, NY 10032, USA \\ Correspondence to: Joshua R. Sonett, MD. Professor and Chief Thoracic Surgery, Director Price Center for Comprehensive Chest Care, Columbia \\ University, New-York Presbyterian Hospital, New York, NY 10032, USA. Email: Js2106@columbia.edu.
}

\begin{abstract}
The role of the thymus in the development and pathogenesis of acetylcholine antibody myasthenia gravis is well documented. The ability of thymectomy to alter the course of the disease has been debated for many years, and now finally has been proven to clearly improve patients with the publication of the prospective randomized trial of thymectomy versus medical therapy alone. The trial definitively proves the validity of thymectomy for non-thymomatous myasthenia gravis, the maximal thymectomy surgical resection tested in the trial was critically chosen to address the anatomic presence of thymic tissue outside of the confines of the defined lobes of the thymus in the neck and mediastinum. Given the clear results of the trail, presently maximal thymectomy is the only proven valid resection in the treatment of myasthenia gravis.
\end{abstract}

Keywords: Maximal thymectomy; myasthenia gravis; MGTX trial

Received: 24 April 2018; Accepted: 23 May 2018; Published: 22 August 2018.

doi: 10.21037 /jovs.2018.05.28

View this article at: http://dx.doi.org/10.21037/jovs.2018.05.28

\section{Defining maximal thymectomy}

The only prospectively proven surgical procedure in the treatment of non-Thymomatous Myasthenia Gravis is the resection performed in an extended trans-sternal thymectomy (Figure 1). In assessing or quantitating the defined validity of "Maximal" thymectomy in the treatment of Non-thymomatous myasthenia gravis one must understand the historical and surgical evolution of thymectomy. The term Maximal thymectomy was codified in our surgical literature in 1988 with the publication by Dr. Jaretzki of his "maximal" thymectomy technique (1) and results (2). In these papers he described and advocated for a combined cervical incision and median sternotomy for complete dissection of mediastinal and cervical tissue in order to complete a maximal thymectomy. These publications were preceded by a manuscript in 1977, that described the combined cervical and sternotomy incision, but called the procedure a "total thymectomy" (3). The surgical strategies to achieve the resection equivalent to the cervical and sternal approach evolved over the years, with the goal of maintaining similar tissue resection with evolutionary decreases in the morbidity of the incisional approach. The initial reports and analysis where by Masaoka and Monden and then Moulder et al., who described and published the results of the extended transsternal thymectomy, in which the surgeon extends the cephalad portion of the sternal incision to complete the cervical portion of the procedure $(4,5)$. This provided maximal resection with a single wound and less formal dissection of the recurrent nerves, thus avoiding excess morbidity $(6,7)$ and this began the evolution of decreasing incisions without decrements on resection intent. It was this modified Maximal thymectomy that was further standardized, utilized and prospectively trialed and quantified in the in the international prospective study of thymectomy in myasthenia gravis (8).

\section{Anatomical basis for maximal thymectomy}

Designing and planning any surgical procedure begins with a complete understanding of anatomy. The anatomy of the thymus, as a gland with discrete lobes combined with thymic rests and lobules distributed in the mediastinum and cervical region has been well documented and described 


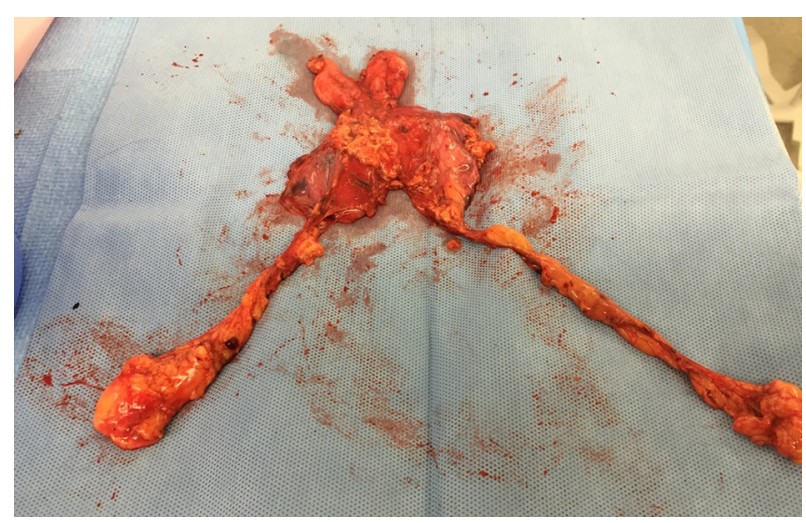

Figure 1 Maximal thymectomy specimen.

(1,9-14). These anatomical facts have been consistently described and validated over time and multiple continents (Figure 2). describes many of the anatomical variances proven over time. Approaches to the resection of this tissue may vary, but each approach should have solutions to achieve the same maximal resection.

\section{Proof and validity of thymectomy in myasthenia gravis}

The surgical treatment of myasthenia gravis (MG) began in earnest in 1941, with Alfred Blalock publishing the first series of the use of thymectomy to treat myasthenia gravis in patients without a thymic mass or thymoma. Multiple retrospective series followed from 1941 to 2016, but despite the robust retrospective data, definitive proof of the effectiveness of thymectomy remained unproven and controversial. Consequently, the majority of neurologists in the world and the consensus neurology guidelines did not definitely recommend thymectomy as a component of the initial treatment. This controversy finally ended in 2016 as the results of the prospective randomized trial of thymectomy in myasthenia gravis definitely proved the beneficial role of thymectomy in acetylcholine positive MG > the study, published in 2016, was a multicenter, prospective, randomized and rater-blinded trial designed to evaluate the effect of thymectomy plus prednisone versus treatment with prednisone alone on improvement of MG symptoms, MG exacerbations, total prednisone and alternative immunosuppression requirements, and treatment-related complications (MGTX trial) (15).

The trial, screened over 1,000 patients and randomized a total of 126 patients between the ages of 16 and 65 with

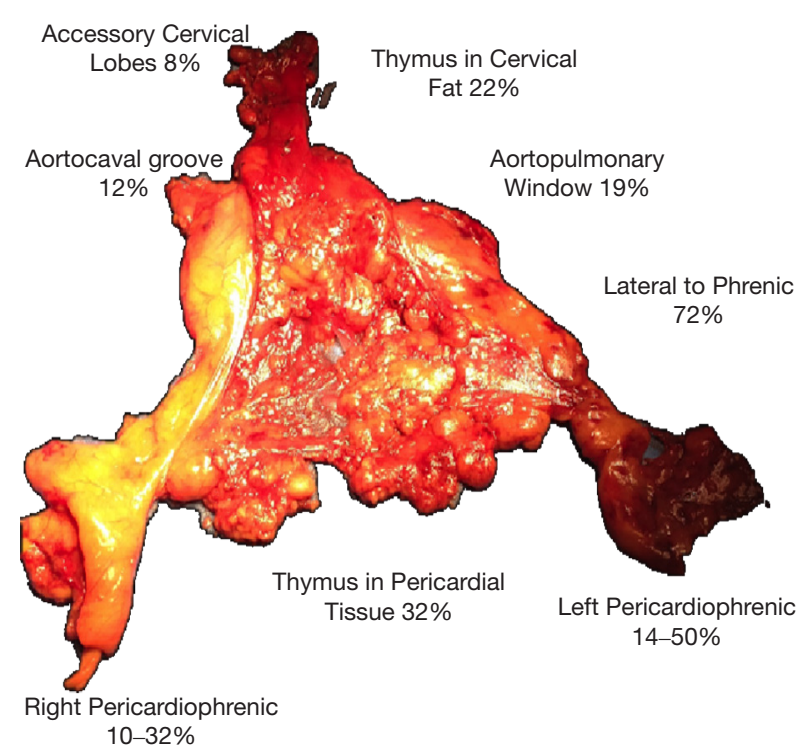

Figure 2 Proven anatomy of the thymus, with documented locations of thymic tissue (1,9-14).

AChR-positive MG, not associated with a thymoma, with disease duration of less than 5 years. Patients Myathenias Gravis Foundation Association (MGFA) class II, III, and IV were included while those with ocular symptoms only or severe disease requiring intubation (class I and class $\mathrm{V}$, respectively) were excluded, as were those who had undergone non-prednisone based immunotherapy (azothriapine, rituximab). Participants were randomized to either undergo extended transsternal thymectomy in addition to a standardized prednisone protocol, or the prednisone protocol alone, and were followed for three years. Surgeons were required to adhere to a prescribed approach and underwent mandatory training to eliminate potential variability introduced by different thymectomy technique (15-17).

The results from this study unequivocally prove that a maximal or complete thymectomy improves clinical outcomes of patients with generalized MG. Patients who were randomized to thymectomy had significantly improved symptoms of MG, as measured by an average quantitative myasthenia score of 6.15 vs. 8.99 , a clinically significant difference in favor of the thymectomy group $(\mathrm{P}>0.0001)$. The lower the quantitative myasthenia score, the better the patient is symptomatically. At the same time temporally, a significantly lower dose of prednisone (44vs. $60 \mathrm{mg}$; $\mathrm{P}<0.001)$ was needed to attain the lower improved neurologic status). Surgery added no significant morbidity 


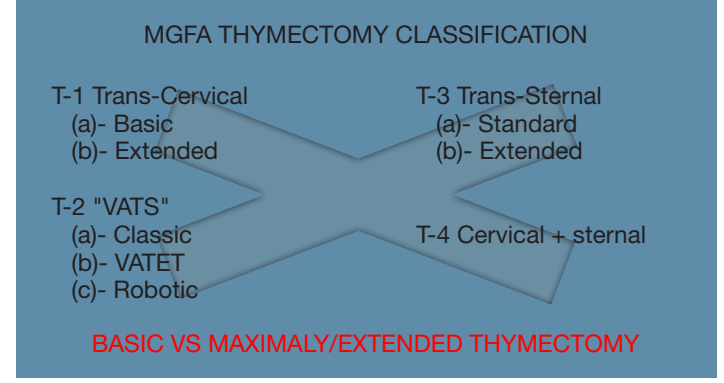

Figure 3 Thymectomy extent classification.

as treatment-associated complications were not different between the two treatment groups over a period of 3 years. Patients who underwent thymectomy also had improved time-weighted average score of daily living scale (2.24 vs. 3.41, $\mathrm{P}=0.008)$. Importantly patients who underwent thymectomy had a significant higher rate of complete pharmacologic remission with minimal-manifestation status at month $36(67 \%$ vs. $47 \%, \mathrm{P}=0.03)$. As well, hospitalizations during the trial period for myasthenia-related symptoms were significantly lower in the thymectomy group $(9 \% \mathrm{vs}$. $37 \%)(15-17)$.

Importantly the results of this trial prove the efficacy of a maximal thymectomy tissue resection, this would apply to any surgical approach to achieve this exact resection but does not support lesser resections. In fact, multiple publications have directly compared maximal resections to lesser resections, and consistently found improved results with a more complete thymectomy $(5,14,18)$. This highlights the pathologic import of the thymic rests, in both maximizing effectiveness of resection, and as well highlighting limitations of surgical cure in myasthenia gravis. Thus, resection techniques should be compared not on surgical approach, but rather on resection (Figure 3).

\section{Techniques addressing maximal thymectomy minimally invasively}

Numerous techniques are now routinely employed by minimally invasive surgeons to address the need of maximal thymectomy in a minimally invasive manner. These include VATS (9) additional robotic techniques as described by Ismail (19) to attain complete resection of both cardiophrenic poles, or by the Toronto (20) group to utilize the cooper retractor and video assistance via the cervical approach. Importantly each group address the intent of maximal thymectomy by enhancing the dissection, rather

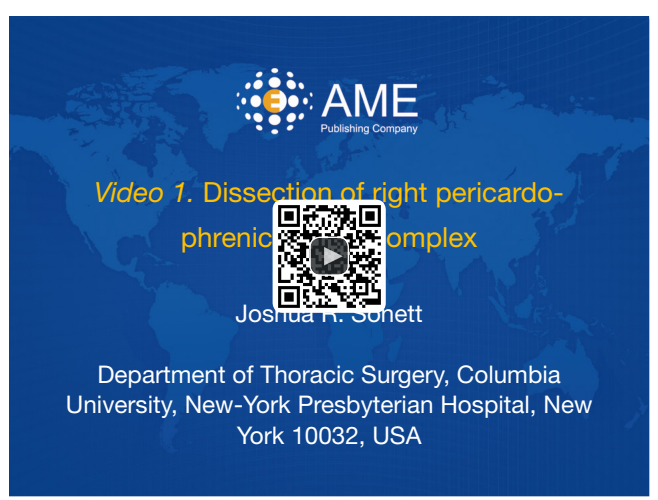

Figure 4 Dissection of right pericardo-phrenic thymic complex (21). Available online: http://www.asvide.com/article/view/26585

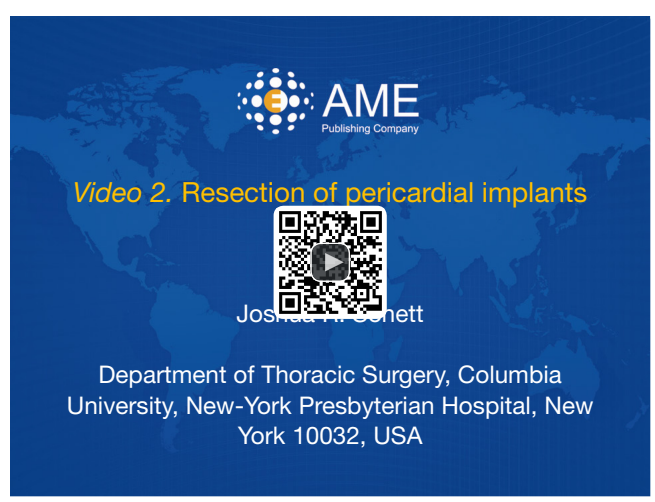

Figure 5 Resection of pericardial implants en-block (22).

Available online: http://www.asvide.com/article/view/26586

than degrading the procedure to attain a minimally invasive approach at any cost. Videoclips of Columbia University approach to some tenets of maximal resection are as follows. Figure 4 addresses the approach the right pericardiophrenic thymic tissue. Figure 5, addresses resection of imbedded thymic rests in the pericardium. Figure 6 addresses tissue lateral to the left phrenic. Figure 7 addresses complete cervical dissection.

\section{The new maximal thymectomy and future directions}

Present day techniques now enable a maximal thymectomy to performed by multiple minimally invasive approaches. These may include cervical with video assistance, vats, rats, sub-xyphoid and variations of all with single incision. Importantly, regardless of approach, the anatomical facts 


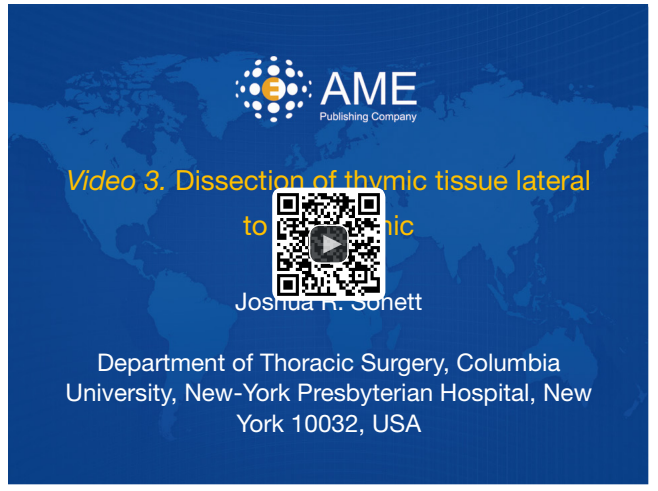

Figure 6 Dissection of thymic tissue lateral to the phrenic (23). Available online: http://www.asvide.com/article/view/26587

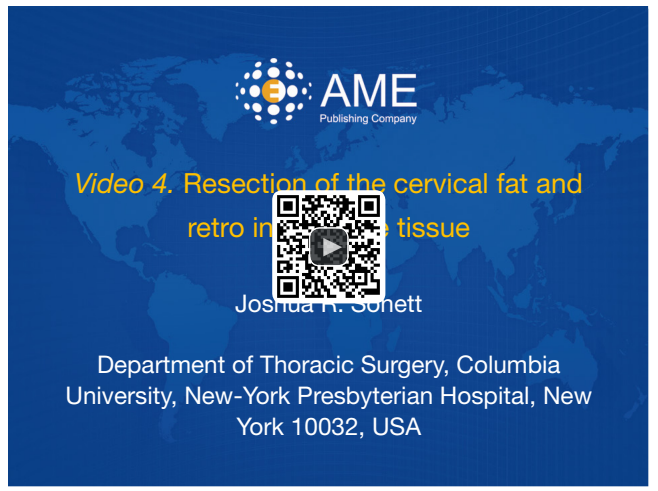

Figure 7 Resection of the cervical fat and retro innominate tissue (24).

Available online: http://www.asvide.com/article/view/26588

of multiple thymic lobes and thymic rests should be considered, and minimally invasive solutions achieved. Differing techniques and tools may be utilized and adapted by surgeons and even modified by regional and national preferences to incisional and cosmetic differences. As the limits of even our rapidly expanding minimally invasive options are belied by the physiologic and cellular immune components of myasthenia gravis, future therapy may integrate medical ablation, as induction or adjuvant therapy to achieve a more immediate and sustained cure for myasthenia gravis.

\section{Conclusions}

Maximal thymectomy is the only proven surgical therapy to improve and alter the course of myasthenia gravis. The absolute validity of the role of maximal thymectomy was finally proven by the prospective randomized trial of thymectomy in acetylcholine positive myasthenia gravis (MGTX trial). The surgical resection tested was based on the diffuse anatomic presence of thymic tissue in the mediastinum and neck, and lesser resections have never been validated nor proven. Although the surgical approach in the trial was by sternotomy, the surgical resection tested can now be performed with minimally invasive approaches. The MGTX trial results should as well highlight the continued import of prospective randomized trials in surgery.

\section{Acknowledgments}

Funding: None.

\section{Footnote}

Provenance and Peer Review: This article was commissioned by the Guest Editor (Tommaso Claudio Mineo) for the series "Mediastinal Surgery" published in Fournal of Visualized Surgery. The article has undergone external peer review.

Conflicts of Interest: The author has completed the ICMJE uniform disclosure form (available at http://dx.doi. org/10.21037/jovs.2018.05.28). The series "Mediastinal Surgery" was commissioned by the editorial office without any funding or sponsorship. The author has no other conflicts of interest to declare.

Ethical Statement: The author is accountable for all aspects of the work in ensuring that questions related to the accuracy or integrity of any part of the work are appropriately investigated and resolved.

Open Access Statement: This is an Open Access article distributed in accordance with the Creative Commons Attribution-NonCommercial-NoDerivs 4.0 International License (CC BY-NC-ND 4.0), which permits the noncommercial replication and distribution of the article with the strict proviso that no changes or edits are made and the original work is properly cited (including links to both the formal publication through the relevant DOI and the license). See: https://creativecommons.org/licenses/by-nc-nd/4.0/.

\section{References}

1. Jaretzki A 3rd, Wolff M. Maximalthymectomy for 
myasthenia gravis: surgical anatomy and operative technique. J Thorac Cardiovasc Surg 1988;96:711-6.

2. Jaretzki A 3rd, Penn AS, Younger DS, et al. Maximal thymectomy for myasthenia gravis: results. J Thorac Cardiovasc Surg 1988;95:747-57.

3. Jaretzki A 3rd, Bethe M, Wolff M, et al. Rational approach to total thymectomy in the treatment of myasthenia gravis. Ann Thorac Surg 1977;24:120-30.

4. Mulder DG, Graves M, Hermann C. Thymectomy for myasthenia gravis: recent observations and comparison with past experience. Ann Thorac Surg 1989;48:551-5.

5. Masaoka A. Monden Y. Comparison of the results of transsternal simple, transcervical simple, and extended thymectomy. Ann N Y Acad Sci 1981;377:755-65.

6. Mulder DM. Extended Transsternal Thymectomy. In: Shields T, LoCicero J, Ponn R, Editors. General thoracic surgery (5th ed.), Lippincott Williams \& Wilkins, 2000:2233-7.

7. Jaretzki A. Transcervical/transsternal "maximal" thymectomy for myasthenia gravis. In: Shields T, LoCicero J, Ponn R, Editors. General thoracic surgery (5th ed.), Lippincott Williams \& Wilkins, 2000:2223-32.

8. Wolfe GI, Kaminski HJ, Jaretzki A, et al. Development of a thymectomy trial in non-thymomatous myasthenia gravis patients receiving immunosuppressive therapy. Ann N Y Acad Sci 2003;998:473-80.

9. Ambrogi V, Mineo TC. Active ectopic thymus predicts poor outcome after thymectomy in class III myasthenia gravis. J Thorac Cardiovasc Surg 2012;143:601-6.

10. Sanei B, Tabatabie SA, Bigdelian H, et al. Distribution of mediastinal ectopic thymic tissue in patients without thymic disease. Adv Biomed Res 2015;4:18.

11. Masaoka A, Nagaoka Y, Kotake Y. Distribution of thymic tissue at the anterior mediastinum: current procedures in thymectomy. J Thorac Cardiovasc Surg 1975;70:747-54.

12. Ashour M. Prevalance of ectopic thymic tissue in myasthenia gravis and its clinical significance. J Thorac Cardiovasc Surg 1995;109:632-5.

13. Fukai I, Funato Y, Mizuno T, et al. Distribution of

doi: 10.21037/jovs.2018.05.28

Cite this article as: Sonett JR. Present validity of "maximal" thymectomy in the treatment of myasthenia gravis. J Vis Surg 2018;4:174. thymic tissue in the mediastinal adipose tissue. J Thorac Cardiovasc Surg 1991;101:1099-102.

14. Sonett JR, Jaretzki A. Thymectomy for Nonthymomatous Myasthenia Gravis - a critical analysis. Ann N Y Acad Sci 2008;1132:315-28.

15. Wolfe GI, Kaminski HJ, Aban IB, et al. Randomized Trial of Thymectomy in Myasthenia Gravis. N Engl J Med 2016;375:511-22.

16. Sonett JR, Bromberger B, Jaretski A. Thymectomy for Non-thymomatous Myasthenia Gravis. In: Kaminiski H, Kusner L, editors. Myasthenia Gravis and Related Disorders third addition. Springer International Press, 2018:199-219.

17. Sonett JR, Magee MJ, Gorenstein L. Thymectomy and myasthenia gravis: A history of surgical passion and scientific excellence. J Thorac Cardiovasc Surg 2017;154:306-9.

18. Zieliński M, Kuzdzal J, Szlubowski A, et al. Comparison of late results of basic transsternal and extended transsternal thymectomy in the treatment of myasthenia gravis. Ann Thorac Surg 2004;78:253-8.

19. Ismail M, Swierzy M, Rückert JC. State of the Art of Robotic Thymectomy. World J Surg 2013;37:2740-6.

20. Donahoe L, Keshavjee S. Video-assisted transcervical thymectomy for myasthenia gravis. Ann Cardiothorac Surg 2015;4:561-3.

21. Sonett JR. Dissection of right pericardo-phrenic thymic complex. Asvide 2018;5:702. Available online: http://www. asvide.com/article/view/26585

22. Sonett JR. Resection of pericardial Implants en-block. Asvide 2018;5:703. Available online: http://www.asvide. com/article/view/26586

23. Sonett JR. Dissection of thymic tissue lateral to the phrenic. Asvide 2018;5:704. Available online: http://www. asvide.com/article/view/26587

24. Sonett JR. Resection of the cervical fat and retro innominate tissue. Asvide 2018;5:705. Available online: http://www.asvide.com/article/view/26588 